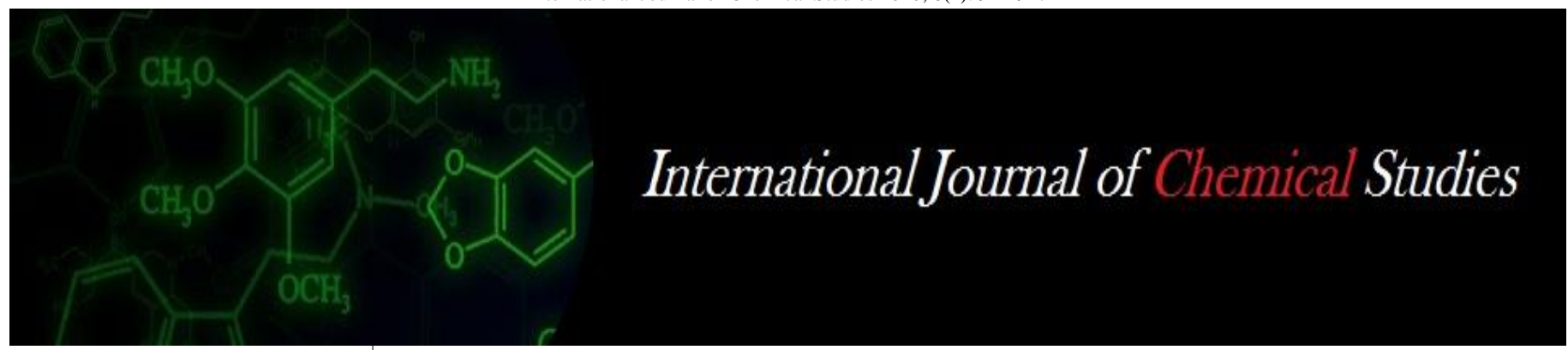

P-ISSN: 2349-8528

E-ISSN: 2321-4902

IJCS 2020; 8(1): 914-917

(C) 2020 IJCS

Received: 14-11-2019

Accepted: 18-12-2019

Maske Sachin V

MIP College of Food Technology,

Aundha (Nag) Dist. Hingoli,

Maharashtra, India

\section{Bhalerao MK}

MIP College of Food Technology,

Aundha (Nag) Dist. Hingoli,

Maharashtra, India

\section{RM Siddiqui}

MIP College of Food Technology,

Aundha (Nag) Dist. Hingoli,

Maharashtra, India

\section{Dr. PP Thorat}

MIP College of Food Technology, Aundha (Nag) Dist. Hingoli,

Maharashtra, India
Corresponding Author:

Maske Sachin V

MIP College of Food Technology,

Aundha (Nag) Dist. Hingoli,

Maharashtra, India

\section{Development of instant UPMA mix with incorporation of Bengal gram and soy flour}

\author{
Maske Sachin V, Bhalerao MK, RM Siddiqui and Dr. PP Thorat
}

DOI: https://doi.org/10.22271/chemi.2020.v8.i11.8366

\begin{abstract}
In the present investigation, the instant UPMA mix was prepared with incorporation of Bengal gram and soy flour. The instant UPMA mix was developed with variation of Bengal gram and soy flour i.e sample A $(15 \%, 5 \%), \mathrm{B}(10 \%, 10 \%)$ and $\mathrm{C}(5 \%, 10 \%)$ and keeping the quantity of semolina as constant. The spice mix is added for betterment of product in the proportion as $20 \%$. The prepared mix was analysed for its proximate composition such as protein, carbohydrate, fat etc. On the basis of sensory evaluation by hedonic scale, the mix prepared with equal quantity of Bengal gram and soy flour (sample B) was found organoleptically accepted as compared to other samples. The proximate composition revealed, the sample $\mathrm{B}$ has lowest moisture content (6.12\%) as compared to control sample $(6.81 \%)$, A $(7.52 \%)$ and C (7.32\%). The protein, fat, carbohydrate and ash content of sample B was found to be $13.34 \%, 8.12 \%$, $59.88 \%$ and $4.12 \%$. The overall accepted prepared mix provides energy to about $376.89 \mathrm{Kcal} / 100 \mathrm{gm}$.
\end{abstract}

Keywords: Instant mix, UPMA mix, soy flour, ready to cook products, pulses based food products

\section{Introduction}

Convenience foods are types of food which imparts convenience to the consumer by way of little or no need of major processing or cooking before consumption. Rapid urbanization, industrialization phenomenon of "working women" recent years and consequent charges in eating habits of consumer have lead to development of instant mixes and Ready to eat foods (RTE) (Rodge et al., 2018) ${ }^{[3]}$.

Rapid urbanization, industrialization and consequent changes in eating habits of people have lead to development of instant dry mixes and ready-to-eat convenience foods (Balasubramanian et al., 2014) ${ }^{[2]}$. Traditional foods have become the first preference of the consumers. Many cereals based traditional foods have been processed and their instant mixes like instant UPMA mix, IDLI mix and dosa mix have been developed.

The indigenous instant food products are prepared at home since ages, but due to the availability of wide range of instant food products in recent years, the consumers are more keen to use the products available in the market using convenient packages at reasonable rate. UPMA is a traditional Indian breakfast dish, cooked as a thick porridge from dry roasted semolina. Various seasonings and vegetables are often added during cooking depending on individual preferences (Ketki et al., 2018) developed an instant wheat semolina based UPMA mix, which could be reconstituted within 4-6 min in boiling water and well accepted by the consumers (Balasubramanian et al., 2014) ${ }^{[2]}$.

Mature chickpeas (cooked) are used to prepare salads, stews, various fried/steamed/fermented snacks (Dhokala). Chickpea grains ground into flour (gram flour/chickpea flour/Besan) and used commonly in Indian cuisines such as Missie Roti, Mirchi Bhajji, Pakodas, Bonda, Boondi, Kadhi, Falafel, Farinata/ Panelle.

Soybean (Glycine max) belonging to family leguminaceae, being rich inedible oil about 18$20 \%$ and high quality protein (40\%).Soybean contains all the three micronutrients required for good nutrition, along with fiber, vitamins and minerals. In addition to nutritive value,soybean has many medicinal and therapeutic values.

Therefore, this work was planned to develop a convenience mix i.e. UPMA from wheat semolina, rosted soyabean semolina, Bengal gram semolina and to evaluate its sensory evaluation and proximate analysis in order to harness the nutritional potential of this valuable crop. An attempt was made to develop soy-fortified instant UPMA mix by incorporating soy semolina and Bengal gram semolina to increase nutritional value of the product. 


\section{Material and Method}

The basic ingredients like wheat semolina, soya semolina, and Bengal gram semolina mustard seeds, salt, green chilli, curry leaves, cumin seeds and coriander leaves were procured from the local market, cleaned and used in the preparation of instant UPMA mix.

\section{Preparation of soy semolina}

Soybean grains were thoroughly cleaned to remove the dust and other foreign materials. The cleaned grains were soaked in water for 6-8 hours and autoclaved for 20 minutes to remove the beany flavour and as well as to enhance easy dehulling. The autoclaved beans were cooled and dried at $60{ }^{\circ} \mathrm{C}$ for about 24 hours. The dried beans were milled to make soy grits and sieved through $80-100$ mesh sieve to separate soy flour (Ketki et al., 2017)

\section{Preparation of Bengal gram semolina}

The Bengal gram dal was converted into semolina by using a flour mill by adjusting clearance between the rotating discs and the obtained semolina was passed through flour sieve to get flour free semolina of uniform size.

\section{Development and formulation of instant UPMA mix}

Preliminary studies were performed for the purpose of identifying the appropriate proportions of ingredients, sample combinations, cooking and accordingly percentage of supplementation was established through sensory evaluation. Several compositions of raw materials and main ingredients were tried to arrive at the desired formulation with optimum percentage as recommended by acceptability studies. All experimental samples were prepared using the traditional method (Ketki et al., 2017).

Table 1: Formulation of instant UPMA mix

\begin{tabular}{|c|c|c|c|c|}
\hline Sample & $\begin{array}{c}\text { Wheat } \\
\text { Semolina }\end{array}$ & Spice Mix & $\begin{array}{c}\text { Bengal gram } \\
\text { Flour }\end{array}$ & Soya Flour \\
\hline Control & 80 & 20 & - & - \\
\hline Sample A & 60 & 20 & 15 & 05 \\
\hline Sample B & 60 & 20 & 10 & 10 \\
\hline Sample C & 60 & 20 & 05 & 15 \\
\hline
\end{tabular}

Control -Wheat semolina: spice mix (80:20).

Sample A - Wheat Semolina: Bengal gram semolina: soya semolina: spice mix (60:15:05:20).

Sample B - Wheat Semolina: Bengal gram semolina: soya semolina: spice mix (60:10:10:20).

Sample C - Wheat Semolina: Bengal gram semolina: soya semolina: spice mix (60:05:15:20).

\section{Preparation of UPMA from instant UPMA mix}

The wheat semolina, Bengal gram semolina and soya semolina were roasted in non-stick pan on slow flame with constant stirring till (5-7 $\mathrm{min})$ it started to give characteristics aroma and colour of a cooked product. Oil $(30 \mathrm{ml})$ was heated in a pan and mustard seed (05 g), fresh green chilies (20 g), curry leaves $(1 \mathrm{~g})$ and Roasted semolina (wheat/ Bengal gram semolina/ soya semolina), salt (05g) and citric acid (0.20 g) were added in the pan and mixed properly. The samples were cooled, packed in container and stored at ambient condition.

\section{Procurement of raw material}

(Wheat Semolina, soya semolina, Bengal gram semolina)

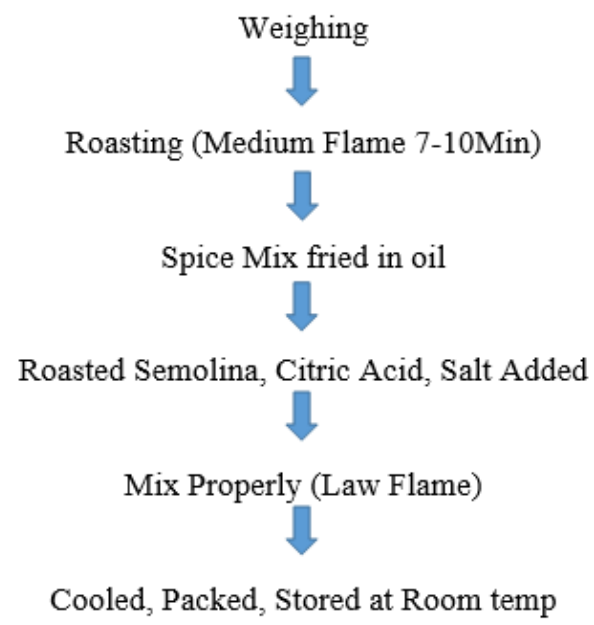

Fig 1: Flow chart of preparation of instant UPMA mix

\section{Reconstitution of instant UPMA mix}

Dry mixes (100 g) of foxtail millet semolina based UPMA were reconstituted with measured amount of hot water (190$200 \mathrm{ml}$ ) and stirred on low flame until the desired consistency was attained (started to leave the pan).

\section{Results and Discussion}

A number of trials were conducted by taking varying combinations of wheat semolina, bengal gram semolina and soya semolina keeping mustard seeds, fresh chilli, curry leaves/dried spices (chilli) level constant with salt, citric acid, hot oil and water. Accordingly, UPMA mix was prepared with 60-80 percent wheat semolina, 05-15 percent Bengal gram semolina, $05-15$ percent soya semolina, 20 percent spice mix and 160-200 ml water for cooking. The control UPMA mix was prepared with wheat semolina $(80 \%)$ and Spice Mix $(20 \%)$. In the primary sensory evaluation test, different UPMA were prepared from different formulations and were evaluated by panelists. The score for the products with 45-95 percent foxtail millet semolina, 20-50 percent wheat semolina, 5 percent soy grits, 15 percent oil were acceptable in terms of all sensory attributes. Panelists suggested the 15 
$\mathrm{ml}$ oil and $200 \mathrm{ml}$ water/100 gm instant mix for improving the texture and softness of modified instant UPMA mix as the UPMA mix with $10 \mathrm{ml}$ oil was too sticky in texture while with $20 \mathrm{ml}$ oil was very oily. Similarly, the pearl millet based UPMA dry mix was developed and ingredients were optimized by (Balasubramanian et al., 2014) ${ }^{[2]}$.

\section{Sensory evaluation of UPMA prepared from instant UPMA mix}

The sensory quality characteristics of the UPMA prepared from various instant mixes were evaluated by panel of 15 trained judges using nine-point hedonic scale (1-dislike extremely, 2-dislike very much, 3-dislike moderately, 4dislike slightly, 5-neither like nor dislike, 6-like slightly, 7like moderately, 8-like very much and 9-like extremely) as described by (Ketki et al., 2017). The samples were identified by code number to the panellists.

Sensory evaluation of UPMA prepared from different formulations of instant UPMA mixes presented in table 2.

Table 2: Sensory evaluation of UPMA prepared from instant UPMA mix

\begin{tabular}{|c|c|c|c|c|c|}
\hline Sample & Appearance and Colour & Taste & Texture & Flavor & Overall acceptability \\
\hline Control & 9 & 8 & 8 & 9 & 8.5 \\
\hline Sample A & 8 & 7 & 6 & 6 & 6.7 \\
\hline Sample B & 8 & 7 & 7 & 8 & 7.5 \\
\hline Sample C & 7 & 7 & 6 & 6 & 6.5 \\
\hline
\end{tabular}

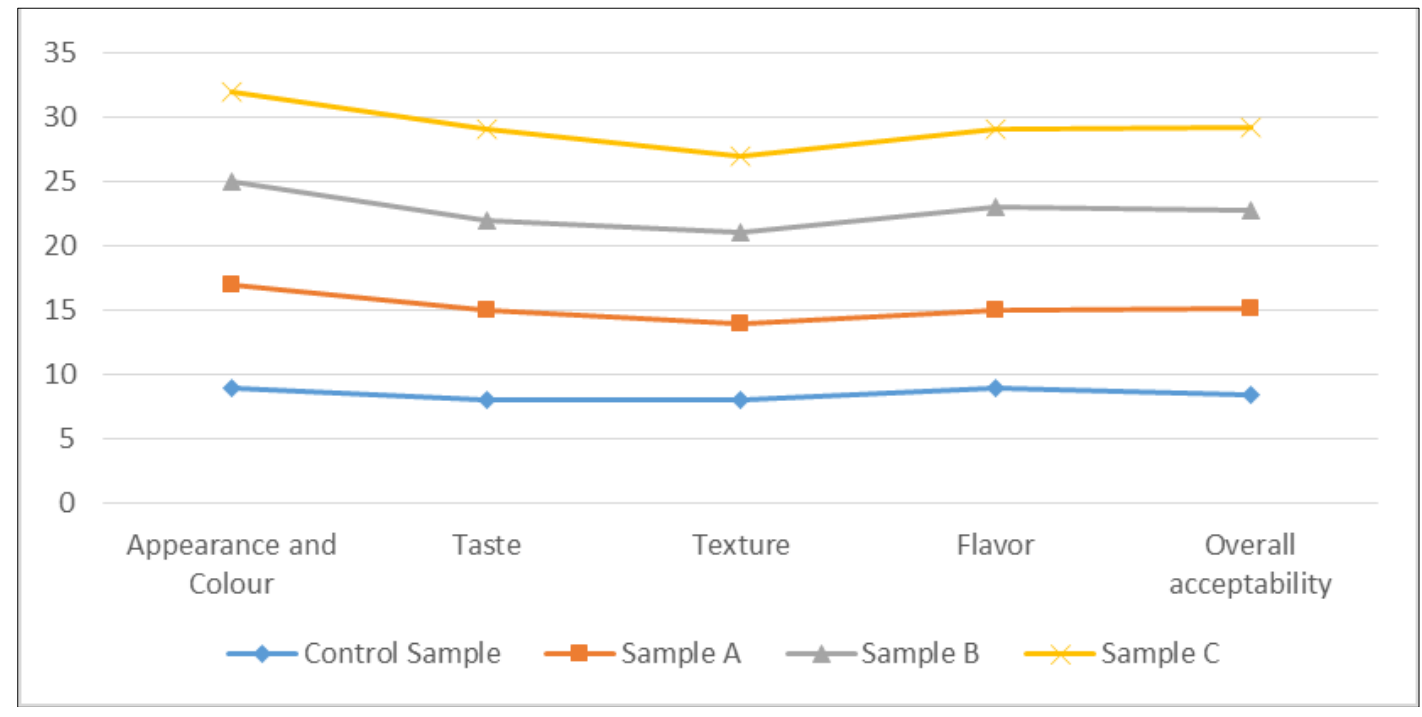

Fig 2: Sensory evaluation of instant UPMA

\section{Proximate analysis of instant UPMA mix}

Proximate analysis of instant UPMA mix presented in table no 3 it showed that the control sample of instant UPMA mix the moisture content of control sample was 6.12 percent, fat content 6.60 percent, protein content 11.02 percent, carbohydrate content 59.12 percent, ash content 3.45 percent and energy value was obtained $349.53 \mathrm{Kcal} / 100 \mathrm{gm}$. The different formulation of instant UPMA mix proximate composition was obtained moisture content of sample A, B, C was $7.52,6.81,7.32$ respectively. The fat content of sample A, B, C was 7.73, 8.12, 9.32 respectively. The protein content of sample A, B, C was 12.43, 13.34, 16.53 percent respectively. Carbohydrate content of sample A, B, C was $60.13,59.88,58.79$ percent respectively. Ash content of sample A, B, C was 4.22, 4.12, 4.53 percent respectively and the energy value obtained from sample A, B, C was 371.55, 376.89, 397.01 Kcal/ 100gm respectively. The study of proximate analysis of instant UPMA mix was done by as compared to the moisture from 6.15 to 7.62 percent, protein 11.30 to 13.84 percent, fat 7.30 to 16.80 percent, carbohydrate 55.16 to 64.07 , ash 2.89 to 4.43 percent, and energy value 371.06 to $427.50 \mathrm{Kcal} / 100 \mathrm{~g}$. (Rodge et al., 2018).

Table 3: Proximate Analysis of instant UPMA mix

\begin{tabular}{|c|c|c|c|c|c|c|}
\hline Sample & $\begin{array}{c}\text { Moisture Content } \\
(\mathbf{\%})\end{array}$ & $\begin{array}{c}\text { Fat Content } \\
(\mathbf{\%})\end{array}$ & $\begin{array}{c}\text { Protein Content } \\
(\boldsymbol{\%})\end{array}$ & $\begin{array}{c}\text { Carbohydrate Content } \\
(\mathbf{\%})\end{array}$ & $\begin{array}{c}\text { Ash Content } \\
(\boldsymbol{\%})\end{array}$ & $\begin{array}{c}\text { Energy Value } \\
(\text { Kcal/100gm) }\end{array}$ \\
\hline Control & 6.18 & 6.60 & 11.02 & 59.12 & 3.45 & 349.59 \\
\hline A & 7.52 & 7.73 & 12.43 & 60.13 & 4.22 & 371.55 \\
\hline B & 6.12 & 8.12 & 13.34 & 59.88 & 4.12 & 376.89 \\
\hline C & 7.32 & 9.32 & 16.53 & 58.79 & 4.53 & 397.01 \\
\hline
\end{tabular}




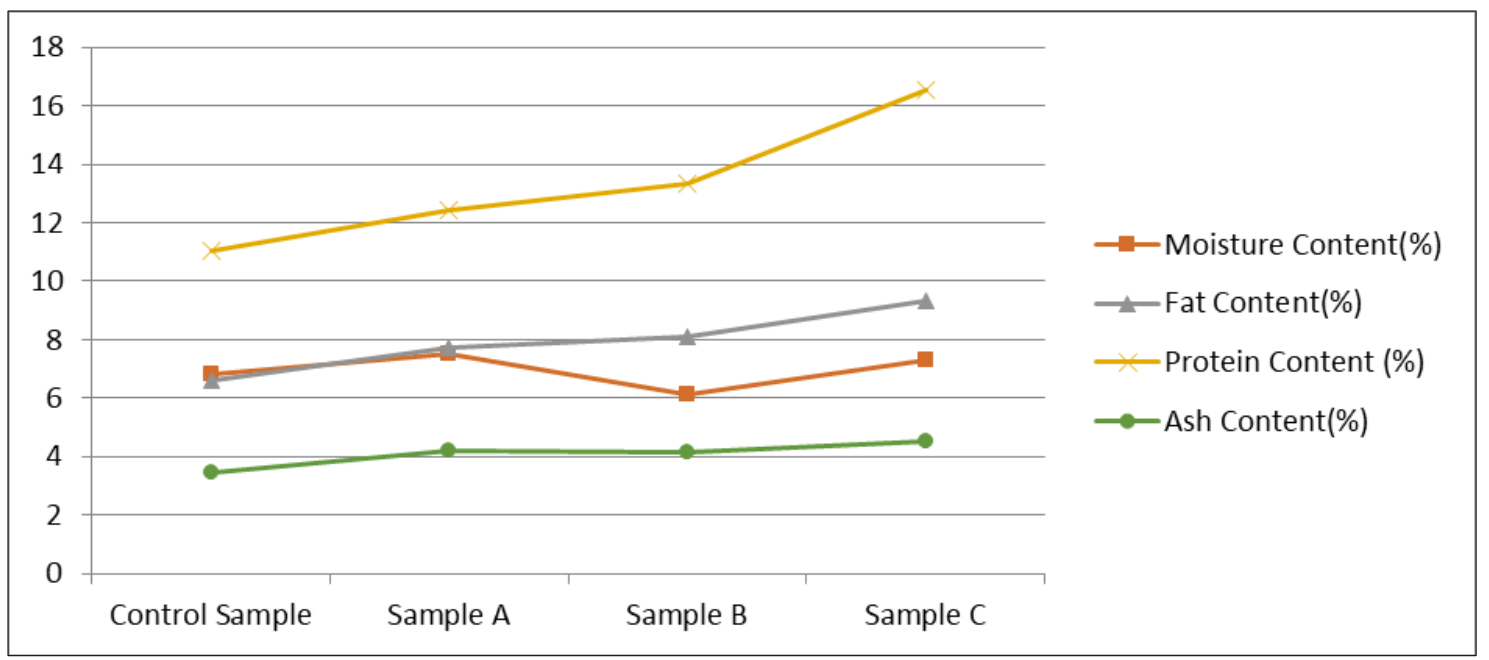

Fig 3: Fig show of control sample of content

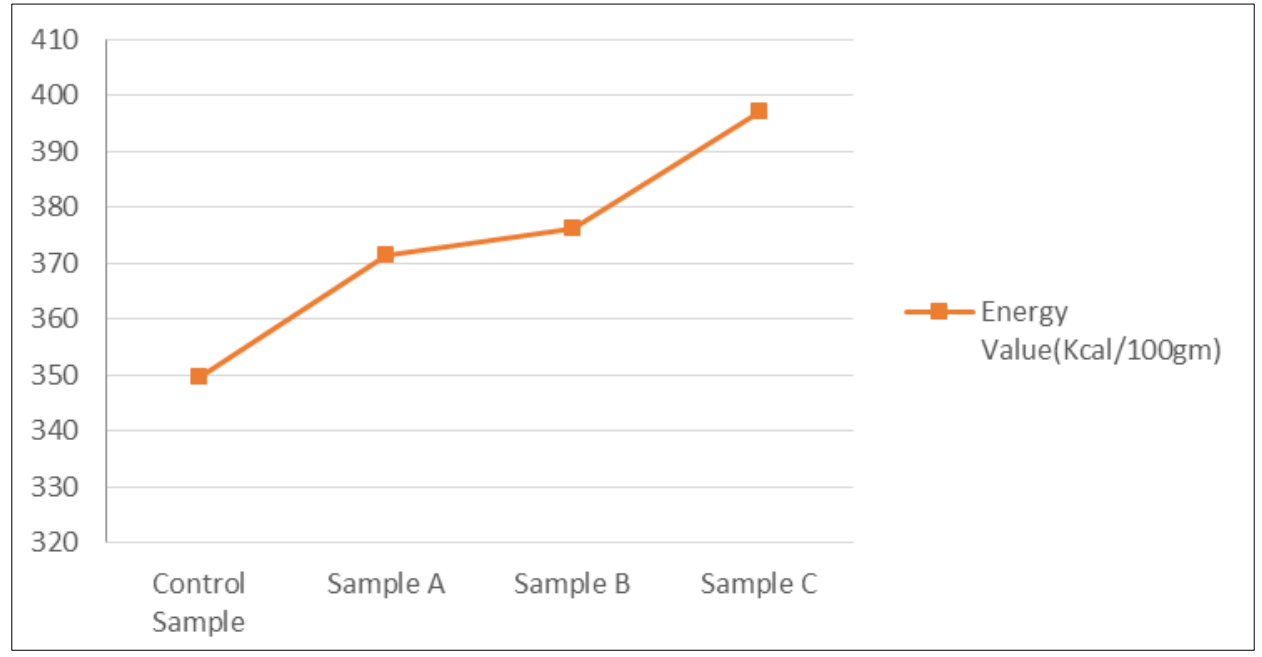

Fig 4: Energy value of instant UPMA mix

\section{Conclusion}

From the present investigation, it was concluded that the mix prepared with same quantity of bengal gram and soy flour with semolina and spice mix was found to be organoleptically accepted. The protein and fat content were found to be increased with increased in concentration of soy flour irreversibly carbohydrate was found to be decreased.

\section{References}

1. AOAC. Official methods of analysis. $18^{\text {th }}$ Edn. Association of Official Analytical Chemists, Washington DC, U.S.A, 2007.

2. Balasubramanian S, Deep NY, Jaspreet K, Tanupriya A. Development and shelf life evaluation of pearl millet based UPMA dry mix. Journal of Food Science and technology. 2014; 51(6):1110-1117.

3. Rodge SM, Bornare DT Formulation and quality evaluation of instant UPMA mix of foxtail millet and garden cress seed. International Journal of Chemical Studies 2018; 6(3):1854-1857.

4. Yadav DK, Wadikar DD. Development and storage stability of RTE Bengal gram (Cicer arietinum) based spiced snacks - Chana Nibble. International Food Research Journal. 2016; 23(1):77-84. 